University of Nebraska - Lincoln

DigitalCommons@University of Nebraska - Lincoln

USGS Staff -- Published Research

US Geological Survey

2013

\title{
Development of an in vitro assay for detecting botulinum neurotoxin type E with application to avian botulism in the Great Lakes
}

\author{
T.M. Piazza
}

University of Wisconsin - Madison, tpiazza@biosentinelpharma.com

D.S. Blehert

U.S. Geological Survey

M.D. Samuel

U.S. Geological Survey

F.M. Dunning

BioSentinel Pharmaceuticals Inc

F.N.Zeytin

BioSentinel Pharmaceuticals Inc

See next page for additional authors

Follow this and additional works at: http:// digitalcommons.unl.edu/usgsstaffpub

Piazza, T.M.; Blehert, D.S.; Samuel, M.D.; Dunning, F.M.; Zeytin, F.N.; and Tucker, W.C., "Development of an in vitro assay for detecting botulinum neurotoxin type E with application to avian botulism in the Great Lakes" (2013). USGS Staff -- Published Research. 768

http://digitalcommons.unl.edu/usgsstaffpub/768

This Article is brought to you for free and open access by the US Geological Survey at DigitalCommons@University of Nebraska - Lincoln. It has been accepted for inclusion in USGS Staff -- Published Research by an authorized administrator of DigitalCommons@University of Nebraska - Lincoln. 
Authors

T.M. Piazza, D.S. Blehert, M.D. Samuel, F.M. Dunning, F.N. Zeytin, and W.C. Tucker 
Development of an in vitro assay for detecting botulinum neurotoxin type $E$ with application to avian botulism in the Great Lakes

T.M. Piazza ${ }^{\text {a,b }}$, D.S. Blehert ${ }^{c}$, M.D. Samuel ${ }^{\text {d }}$, F.M. Dunning ${ }^{\mathrm{b}}$, F.N. Zeytin ${ }^{\mathrm{b}}$, W.C. Tucker ${ }^{\mathrm{b}}$

${ }^{a}$ Department of Forest and Wildlife Ecology, University of WisconsinMadison, Madison, WI, USA

${ }^{\mathrm{b}}$ BioSentinel Pharmaceuticals Inc, Madison, WI, USA

${ }^{c}$ U.S. Geological Survey-National Wildlife Health Center, Madison, WI, USA

${ }^{\mathrm{d}}$ U.S. Geological Survey-Wisconsin Cooperative Wildlife Research Unit, Madison, WI, USA

E-mail address: tpiazza@biosentinelpharma.com (T.M. Piazza).

Purpose of study: Botulinum neurotoxin serotype $\mathrm{E}(\mathrm{BoNT} / \mathrm{E})$ outbreaks in the Great Lakes region cause large annual avian mortality events with an estimated 17,000 bird deaths reported in 2007 alone. It is proposed that environmental conditions following blooms of the native algae Cladophora may promote growth of $C$. botulinum within Great Lakes sediments and subsequent BoNT/E production. BoNT/E may then be mobilized from the lake bed through food chains consisting of exotic species. We set out to develop a sensitive in vitro assay for diagnosis of avian BoNT intoxication and analysis of drivers that contribute to these outbreaks.

Methods used: The BoTest ${ }^{\mathrm{TM}}$ Matrix E BoNT/E detection assay combines immuno-precipitation with high-affinity endopeptidase activity detection by Förster Resonance Energy Transfer to rapidly quantify BoNT/E activity in avian blood and other samples with detection limits comparable to the mouse bioassay.

Summary of results: Based upon the analysis of archived blood samples $(n=87)$ collected from bird carcasses during avian mortality investigations, BoTest ${ }^{\mathrm{TM}}$ Matrix E detected picomolar quantities of BoNT/E following a two-hour incubation and femtomolar quantities of BoNT/ E following extended incubation (24 hours), with $100 \%$ diagnostic specificity and 91\% diagnostic sensitivity. Further, BoNT activity, as determined by the BoTest ${ }^{\mathrm{TM}}$ Matrix E assay, correlated linearly with total BoNT/E protein concentration contained within avian blood samples, as measured by sandwich ELISA ( BoTest $^{\mathrm{TM}}$ Matrix E assay also detected BoNT/E in spiked mussels, fish and seaweed, suggesting its utility for analysis of food web components.

Conclusions: Sensitive in vitro assays for the diagnosis of botulinum intoxication in birds and for the identification of BoNT/E in food web components will facilitate understanding of environmental toxin mobilization pathways and will provide useful tools for the conservation of bird species in the Great Lakes region.

http://dx.doi.org/10.1016/j.toxicon.2012.07.098 